\title{
ANALISIS LEAN MANUFACTURING DENGAN VALUE STREAM MAPPING UNTUK MENGIDENTIFIKASI WASTE PADA UD EXECUTIVE MAKMUR ABADI
}

\author{
Nurullaily Kartika \& Intan Yulfi Latifah \\ Departemen Manajemen, Universitas Airlangga \\ e-mail: nurullaily@feb.unair.ac.id
}

\begin{abstract}
This study focuses on the broom production process in MSMEs. The main purpose of investigating is identifying the waste that occurs in the production process so that it can be done the easiest way to improve the quality and competitiveness of broom products at UD. This study uses lean manufacturing in eliminating waste using value stream mapping tools and Fishbone diagrams. The results of this analysis showed that non-value added activity (NVA) was $88.7 \%$. The value added (VA) activity was $10.7 \%$ and the required but non-value added (NNVA) activity had the lowest proportion of the three other activities, namely $0.6 \%$. There are four types of waste that occur, namely waste of defects of $21.95 \%$, waste of overproduction of $19.51 \%$, waste of waiting $17.07 \%$, and waste of waiting of defects of $17.07 \%$.
\end{abstract}

Keywords: lean manufacturing, waste, MSMEs, value stream mapping

\section{PENDAHULUAN}

UMKM merupakan sektor penting dalam pertumbuhan ekonomi karena dalam kurun waktu lima tahun terakhir. UMKM berkontribusi menyumbang angka pada produk domestik bruto (PDB) sebanyak 2,5\% dari 57,84\% menjadi 60,34\% di tahun 2016 (www.kompas.com). Untuk meningkatkan kinerja bisnis dari UMKM perlu meningkatkan produktivitas dan output perusahaan, salah satunya dengan konsep lean manufacturing.

Fokus utama lean manufacturing adalah mengurangi (waste) dari industri untuk meningkatkan nilai pelanggan sehingga perusahaan menjadi lebih kompetitif menurut Liker (1998). Lean memiliki sistem yang berfokus pada identifikasi dan eliminasi aktivitas-aktivitas yang tidak memberikan nilai tambah (non-value added activities) dalam proses produksi (untuk bidang manufaktur) atau operasi (untuk bidang jasa) dan supply chain management yang berkaitan langsung dengan pelanggan (Womack \& Jones, 2003). Waste pada lean manufacturing digolongkan menjadi tujuh macam (Hines \& Rich, 1997) yaitu produksi yang berlebihan (overproduction), waktu tunggu (waiting), transportasi yang berlebihan (transportation), proses yang tidak perlu (inappropriate processing), persediaan yang berlebihan (unnecessary inventory), pergerakan yang tidak perlu (unnecessary movement), dan produk cacat (defect).

Dalam konteks manufaktur, terdapat tiga tipe aktivitas yang terjadi pada konteks manufaktur yaitu aktivitas non-value adding (NVA), necessary but non-value adding (NNVA), dan valueadding (VA) (Hines \& Rich, 1997). NVA merupakan waste murni dan tergolong ke dalam aktivitas tidak penting yang harus dieliminasi. NNVA merupakan waste yang masih diperlukan karena adanya prosedur operasi saat ini. Sedangkan VA merupakan aktivitas mengubah dan 
memproses bahan mentah atau setengah jadi melalui tenaga kerja manual.

UD Executive Makmur Abadi (EMA) adalah salah satu UKM yang memproduksi alatalat kebersihan seperti sapu, pel, keset, dan gantungan baju. Meskipun usaha dagang ini memiliki lini produk yang sangat beragam, dalam penelitian ini menggunakan lini produk sapu sebagai objek penelitian. Sapu yang diproduksi beraneka ragam berdasarkan bahan yang dipakai seperti senar, ijuk, dan rayung. Lini produk sapu dianggap penting karena memberikan kontribusi paling besar pada penjualan UD Executive Makmur Abadi. Dalam pengamatan awal diketahui terdapat waste berupa banyaknya produk tidak terjual karena cacat sebesar 25\% per tahun. Selain itu, waste juga terjadi dilihat dari banyaknya produk yang berada di inventory pada waktu yang lama. Pada bulan-bulan tertentu seperti bulan Juni, Juli, Agustus, dan September, sapu memiliki permintaan tinggi. Dengan demikian, diketahui masa simpan sapu selama delapan bulan (Januari, Februari, Maret, April, Mei, Juni, Oktober, November, dan Desember) dianggap terlalu lama. Production lead time yang dibutuhkan oleh sapu tergolong lama dibandingkan dengan produk lain yaitu kurang lebih empat hari. Keadaan ini memunculkan masalah lain pada waktu tunggu. Pada UD Executive Makmur Abadi diketahui bahwa area yang digunakan untuk memproses produk terpisah-pisah dan tidak terintegrasi pada satu tempat sehingga akan membutuhkan waktu untuk memindahkan barang dari gudang ke toko. Perpindahan barang ini mengacu pada transpor di mana secara ekstrem segala pergerakan di pabrik dapat dipandang sebagai waste ditambah lagi dengan adanya penanganan ganda dan pergerakan berlebihan dapat mengakibatkan rusak pada barang (Hines \& Rich, 1997).
Waste yang terjadi di UD Executive Makmur Abadi perlu untuk dianalisis lebih lanjut karena dapat menurunkan performa perusahaan tersebut. Dalam mengidentifikasi waste diperlukan adanya alat yang dapat membantu proses penelitian. Tool yang digunakan dalam penelitian ini adalah value stream mapping (VSM) karena VSM adalah alat penting yang akan membantu manajer untuk membantu kondisi operasional saat ini dan melihat kesempatan untuk meningkatkan kinerja operasional (Jasti \& Sharma, 2014). Selanjutnya, usulan perbaikan diperlukan untuk meningkat-kan performa perusahaan. Oleh karena itu, untuk memberikan usulan perbaikan pada proses produksi UD Executive Makmur Abadi, penelitian ini menggunakan diagram fishbone.

\section{METODOLOGI}

Secara umum terdapat dua tahap dalam penelitian ini, yakni tahapan awal yang meliputi observasi dan pengumpulan data termasuk wawancara lalu dilanjutkan dengan tahapan analisis data yang meliputi current state mapping, tool value stream mapping (VSM), diagram fishbone, dan future stream mapping.

\section{Tahap Pengumpulan Data}

Observasi dilakukan untuk mengetahui proses produksi sapu yang dihasilkan oleh UD Executive Makmur Abadi. Hal ini berfungsi untuk mengetahui apa saja waste yang dihasilkan dalam proses produksi. Bagan proses produksi sapu dapat dilihat pada Gambar 1.

Selain observasi pada proses produksi sapu, tahapan awal juga melingkupi pengumpulan informasi, guna mendapatkan gambaran keseluruhan proses produksi mulai dari pemesanan 


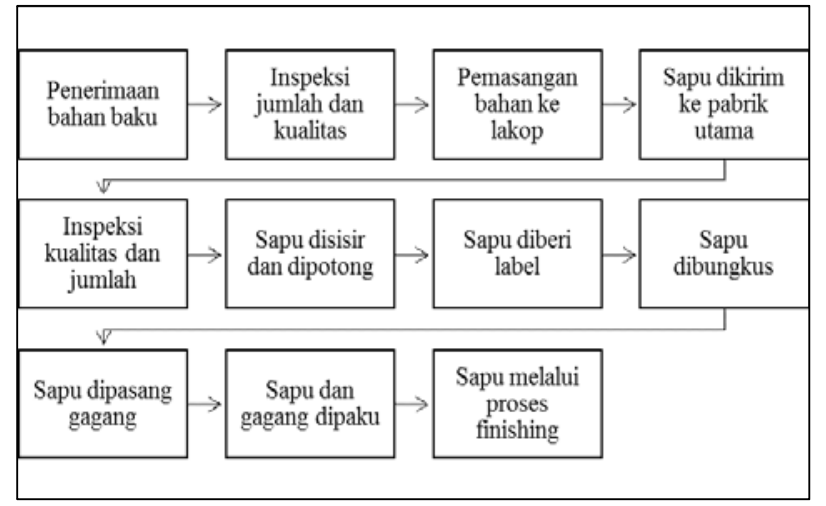

Gambar 1 Proses Produksi Sapu

hingga pengiriman produk ke customer. Hal ini dilakukan melalui wawancara dengan pemilik perusahaan. Aliran informasi meliputi tahap purchasing hingga proses produksi sapu yang dimulai dari tahapan planning hingga finishing.

\section{Tahap Analisis Current State Mapping}

Data yang telah dikumpulkan kemudian diolah menjadi peta kondisi saat ini (current state mapping). Peta kondisi saat ini merupakan pemetaan yang digunakan untuk menggambarkan proses produksi pada sebuah perusahaan dengan menggunakan simbol-simbol tertentu. Pada peta kondisi saat ini dapat dilihat aliran fisik maupun informasi sehingga memudahkan peneliti untuk menganalisis proses produksi yang sedang terjadi. Peta kondisi saat ini menggambarkan alur pro-

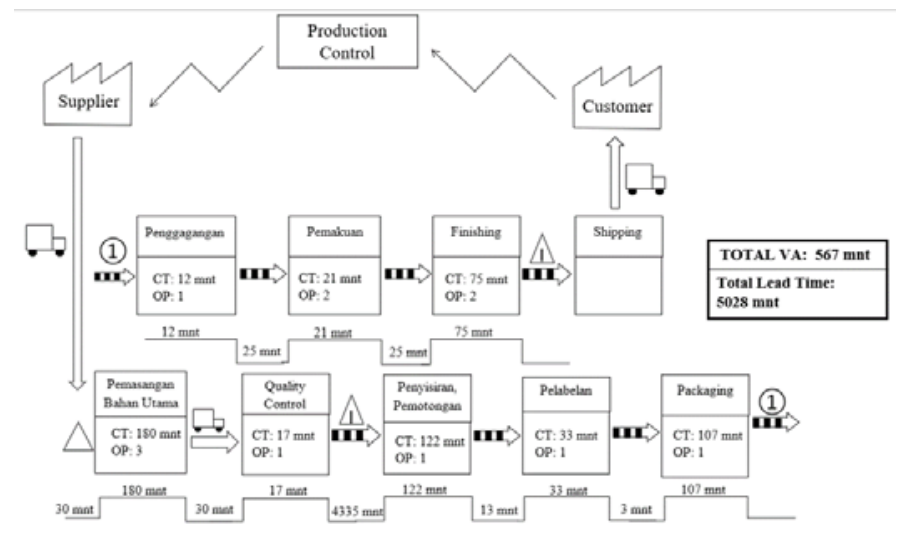

Gambar 2 Current State Mapping duksi, proses produksi, waktu yang digunakan, jumlah operator, aliran informasi, persediaan, dan proses pengiriman.

\section{Value Stream Analysis Tool}

Value Stream Mapping (VSM) adalah seperangkat metode untuk secara visual menampilkan aliran bahan dan informasi melalui proses produksi (Goriwondo et al., 2011). Menurut Kalsaas (2002), VSM adalah alat kualitatif yang mengurangi jalur persediaan dan mengarah pada pengurangan waktu proses. Rother dan Shook (2003) melaporkan bahwa di mana pun produk dikembangkan untuk pelanggan, di saat itulah pasti terdapat aliran nilai.

Value stream mapping memiliki tujuh alat yang berguna untuk mengidentifikasi jenis pemborosan yang terjadi pada suatu perusahaan (Hines dan Rich, 1997). Alat tersebut yaitu process activity mapping (PAM), supply chain response matrix (SCRM), production variety funnel (PVF), quality filter mapping (QFM), demand amplification mapping (DAM), decision point analysis (DPA), dan physical structure (PS) yang masing-masing memiliki korelasi terhadap tujuh pemborosan yang telah dijelaskan oleh Hines \& Taylor. Pemilihan tools VALSAT dilakukan dengan memberikan bobot yang menjadi pengaruh waste terhadap alat yang digunakan. Pembobotan pemborosan dilakukan dengan menyebarkan kuesioner kepada para karyawan UD Executive Makmur Abadi dengan skala keparahan pemborosan dari nol sampai empat.

\section{Analisis Process Activity Mapping (PAM)}

Process activity mapping (PAM) digunakan untuk mengeliminasi pemborosan pada tempat kerja, inkonsistensi dan irasionalitas, dan dapat menyediakan barang dan jasa berkualitas tinggi 
secara mudah, cepat, dan murah. Process activity mapping berisikan daftar aktivitas yang dilakukan di dalam proses produksi sapu ijuk dengan data yang diperlukan seperti jarak setiap aktivitas dan waktu yang dibutuhkan untuk menyelesaikan setiap aktivitas. Data diperoleh dari proses pengamatan langsung dan melalui wawancara dengan pemilik perusahaan.

\section{Diagram Fishbone}

Diagram fishbone merupakan diagram yang berbentuk tulang ikan dan digunakan untuk mengetahui penyebab dari suatu masalah. Menurut Islam et al. (2016), diagram ini berfungsi dalam membantu identifikasi penemuan akar masalah, kemacetan dalam suatu proses, serta letak dan sebab suatu proses tidak berjalan. Diagram fishbone memiliki lima kategori yang dikelompokkan sebagai penyebab masalah (Gaspersz, 2002). Lima kategori tersebut adalah manusia (man), cara (method), mesin (machine), bahan (material), dan lingkungan (environment). Melalui diagram fishbone kemudian dapat dikemukakan usulan perbaikan.

\section{Future State Mapping}

Future state mapping atau pemetaan kondisi masa depan menggambarkan bagaimana proses produksi yang ideal untuk dilakukan oleh perusahaan. Peta kondisi masa depan berisi perbaikan yang diusulkan dari analisis CSM dan PAM dengan melakukan diskusi kepada pihak perusahaan terkait dengan sumber daya yang dimiliki.

\section{HASIL DAN PEMBAHASAN}

Pembahasan penelitian dimulai dari pemeringkatan pemborosan yang dihasilkan melalui tool VALSAT hingga future stream mapping yang digunakan sebagai saran perbaikan bagi perusahaan.

\section{Perhitungan VALSAT}

Hasil dari penyebaran kuesioner memberikan perhitungan mengenai pemborosan yang sering terjadi di UD Executive Makmur Abadi. Berikut adalah hasil pemeringkatan pemborosan yang terjadi.

Tabel 1 Hasil Pemeringkatan Pemborosan

\begin{tabular}{|l|c|c|c|}
\hline \multicolumn{1}{|c|}{$\begin{array}{c}\text { Jenis } \\
\text { Pemborosan }\end{array}$} & $\begin{array}{c}\text { Rata- } \\
\text { Rata }\end{array}$ & Persentase & Peringkat \\
\hline Defects & 2,25 & $21,95 \%$ & 1 \\
\hline Overproduction & 2 & $19,51 \%$ & 2 \\
\hline Waiting & 1,75 & $17,07 \%$ & 3 \\
\hline $\begin{array}{l}\text { Unnecessary } \\
\text { inventory }\end{array}$ & 1,75 & $17,07 \%$ & 4 \\
\hline $\begin{array}{l}\text { Unnecessary } \\
\text { motion }\end{array}$ & 1,25 & $12,20 \%$ & 5 \\
\hline $\begin{array}{l}\text { Innapropriate } \\
\text { processing }\end{array}$ & 1 & $9,76 \%$ & 6 \\
\hline $\begin{array}{l}\text { Excessive } \\
\text { transportation }\end{array}$ & 0,25 & $2,4 \%$ & 7 \\
\hline
\end{tabular}

Hasil dari tabel pemeringkatan pemborosan menunjukkan terdapat empat jenis tipe pemborosan yaitu defects, overproduction, waiting, dan unnecessary inventory dengan persentase paling tinggi di antara tujuh lainnya. Defects dapat berupa kerusakan pada plastik pembungkus sapu, kesalahan pemilihan bahan utama, dan ijuk, rayung, atau senar rontok karena terlalu lembab. Overproduction dapat terjadi berupa penumpukan sapu di persediaan akhir. Waiting dapat berupa proses tunggu pengerjaan sapu yang memakan waktu lama karena jarak pengerjaan terlalu jauh atau minimnya penggunaan mesin. Sedangkan untuk unnecessary inventory dapat berupa penumpukan produk pada work in process. Empat pemborosan teratas tersebut dieliminasi menggunakan value stream map. 
Tabel 2 Hasil Perhitungan Tools VALSAT

\begin{tabular}{|l|c|c|c|c|c|c|c|}
\hline \multicolumn{1}{|c|}{ Waste } & PAM & SCRM & PVF & QFM & DAM & DPA & PS \\
\hline Overproduction & 2 & 12 & & 2 & 12 & 12 & \\
\hline Waiting & 15,75 & 15,75 & 1,75 & & 10,5 & 10,5 & \\
\hline $\begin{array}{l}\text { Excessive } \\
\text { transportation }\end{array}$ & 2,25 & & & & & & 0,25 \\
\hline $\begin{array}{l}\text { Inappropriate } \\
\text { processing }\end{array}$ & 9 & & 6 & 1 & & 1 & \\
\hline $\begin{array}{l}\text { Unnecessary } \\
\text { inventory }\end{array}$ & 10,5 & 15,75 & 10,5 & & 15,75 & 10,5 & 1,75 \\
\hline $\begin{array}{l}\text { Unnecessary } \\
\text { motion }\end{array}$ & 11,25 & 1,25 & & & & & \\
\hline Defects & 2,25 & & & 20,25 & & & \\
\hline \multicolumn{1}{|c|}{ TOTAL } & 53 & 44,75 & 18,25 & 23,25 & 38,25 & 34 & 2 \\
\hline
\end{tabular}

Skor terbanyak diperoleh dari process activity mapping dengan skor 53 sehingga process activity mapping layak menjadi tools yang dipilih untuk penelitian. Pada penelitian ini menggunakan satu tools sebagai alat penelitian karena tools yang terpilih memiliki korelasi paling tinggi di antara tools lainnya.

\section{Analisis Process Activity Mapping (PAM)}

Setiap aktivitas yang tercatat dikategorikan menjadi empat tipe aktivitas yaitu operation, transport, inspection, delay, dan storage. Pengelompokan ini bertujuan untuk menentukan aktivitas yang termasuk ke dalam value added (VA), necessary but non value added (NNVA), atau non-value added (NVA). Berikut ditampilkan ringkasan hasil pemetaan PAM.

Tabel 3 Ringkasan Hasil Pemetaan PAM

\begin{tabular}{|c|c|c|c|c|c|c|}
\hline Aktivitas & Jumlah & Persentase & $\begin{array}{c}\text { Waktu } \\
\text { (Menit) }\end{array}$ & $\%$ & $\begin{array}{c}\text { Total } \\
\text { Waktu }\end{array}$ & $\begin{array}{l}\text { Total } \\
\text { Jarak }\end{array}$ \\
\hline Operation & 7 & $30,4 \%$ & 550 & $10,7 \%$ & \multirow{10}{*}{$\begin{array}{l}5.120 \\
\text { menit }\end{array}$} & \multirow{10}{*}{$\begin{array}{c}17.036,5 \\
\text { meter }\end{array}$} \\
\hline Transport & 11 & $47,8 \%$ & 188 & $3,7 \%$ & & \\
\hline Delay & 2 & $8,7 \%$ & 4.350 & $85 \%$ & & \\
\hline Inspection & 2 & $8,7 \%$ & 32 & $0,6 \%$ & & \\
\hline Storage & 1 & $4,4 \%$ & 0 & $0 \%$ & & \\
\hline Total & \multicolumn{2}{|r|}{23} & \multicolumn{2}{|c|}{5.120} & & \\
\hline VA & 7 & $30,4 \%$ & 550 & $10,7 \%$ & & \\
\hline NVA & 13 & $60,9 \%$ & 4.538 & $88,7 \%$ & & \\
\hline NNVA & 3 & $12 \%$ & 32 & $0,6 \%$ & & \\
\hline Total & \multicolumn{2}{|r|}{23} & \multicolumn{2}{|c|}{5.120} & & \\
\hline
\end{tabular}

Aktivitas delay dan transport menyebabkan nilai NVA tinggi. Delay terjadi ketika proses berhenti karena menunggu kedatangan bahan baku dari proses sebelumnya, mesin yang kurang memadai sehingga membuat proses berlangsung lama, dan proses penyimpanan sementara yang seharusnya dapat dieliminasi. Sedangkan transpor terjadi karena jarak antar proses yang terlalu jauh.

Aktivitas operasi sebesar 10,7\% termasuk dalam aktivitas VA yang harus dilakukan oleh perusahaan untuk memproses bahan baku mentah menjadi produk jadi sehingga aktivitas ini tidak dapat dieliminasi.

Aktivitas NNVA memiliki persentase paling rendah dari ketiga aktivitas lainnya yaitu $0,6 \%$. Aktivitas NNVA meliputi inspection yang digunakan untuk menghindari penerimaan produk cacat oleh pelanggan, menghindari terjadinya kesalahan pembelian bahan baku, dan menghindari terjadinya proses rework.

\section{Analisis Diagram Fishbone}

Pada penelitian ini diketahui pemborosan tertinggi yaitu defects, overproduction, waiting, dan unnecessary inventory melalui penyebaran kuesioner kepada para karyawan perusahaan yang kemudian dilakukan perhitungan pembobotan pemborosan. Keempat pemborosan tersebut akan dianalisis penyebabnya menggunakan diagram tulang ikan untuk kemudian diberikan usulan perbaikan.

\section{Waste of Defects}

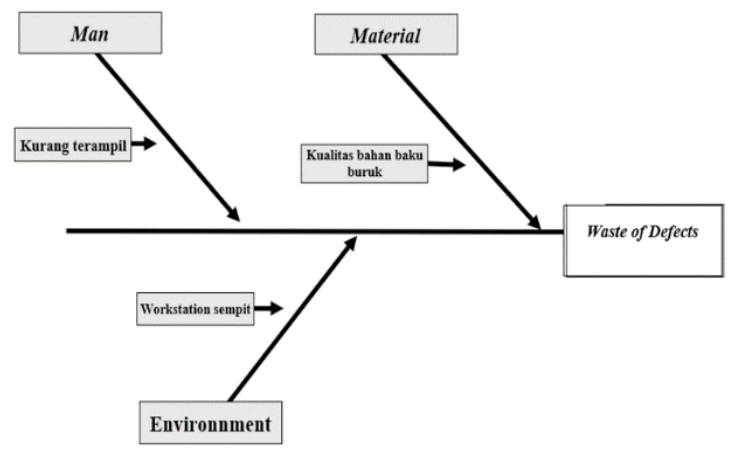

Gambar 3 Waste of Defects 
Pemborosan jenis defect memiliki nilai tertinggi yaitu 2,25. Terdapat tiga kategori pemborosan di sini, yakni man, material, dan environment. Waste pada man terjadi ketika karyawan yang terlibat dalam proses produksi tidak terampil. Pemborosan sering terjadi karena sapu yang dihasilkan dari proses ini memiliki kualitas di bawah standar seperti proporsi bahan tebal dan tipis yang tidak konsisten sehingga diperlukan proses pengerjaan ulang (rework) yang dapat merugikan perusahaan.

Waste pada material secara umum disebabkan oleh kualitas bahan baku yang buruk. Pada proses pengemasan sering terjadi kerusakan seperti plastik robek dan tidak tertutup dengan rapat. Hal ini merupakan masalah utama yang berasal dari kualitas plastik yang digunakan untuk membungkus sapu setengah jadi. Selain itu, lakop sapu yang memiliki ketebalan tipis mudah sobek ketika gagang sapu dipaksa masuk ke dalam lakop. Gagang sapu yang dimiliki berasal dari beberapa vendor sehingga kualitas yang dimiliki tidak homogen. Heterogentitas gagang ini menyebabkan proses pemakuan menjadi tidak kuat dikarenakan struktur kayu yang terlalu keras untuk ditembus oleh paku. Sedangkan dari sisi environment, waste terjadi karena workstation yang sempit. Hal ini menyebabkan barang yang harusnya keluar dahulu menjadi tertimbun dan mengakibatkan cacat. Cacat yang sering terjadi pada proses penggagangan di antaranya plastik pembungkus ijuk yang sering sobek karena tergesek dengan produk yang membebaninya. Selain itu, penumpukan yang lama juga mengakibatkan cacat ijuk menjadi lembab dan mudah rontok.

\section{Waste of Overproduction}

Waste of overproduction menempati skor tertinggi kedua dengan skor 2 pada pembobotan

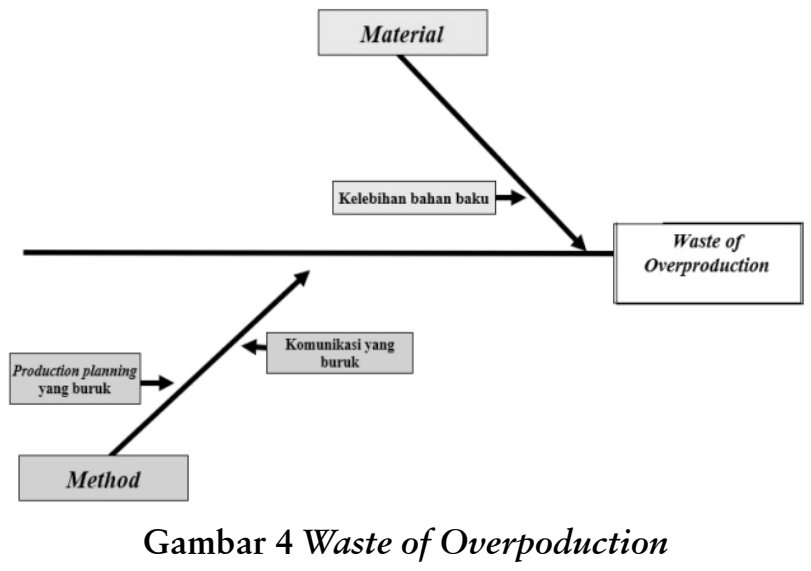

kuesioner. Overproduction terjadi ketika produksi barang melebihi dari permintaan sehingga terdapat penumpukan pada persediaan. Kategori method dan material pada diagram fishbone dapat digunakan untuk menentukan penyebab pemborosan. Pemborosan berupa produksi berlebih terjadi karena perencanaan produksi yang buruk dan komunikasi yang tidak terintegrasi. Perusahaan belum memiliki kemampuan untuk melakukan peramalan penjualan sehingga proses produksi dilakukan berdasarkan purchase order dari pelanggan dan ketersediaan bahan baku.

\section{Waste of Waiting}

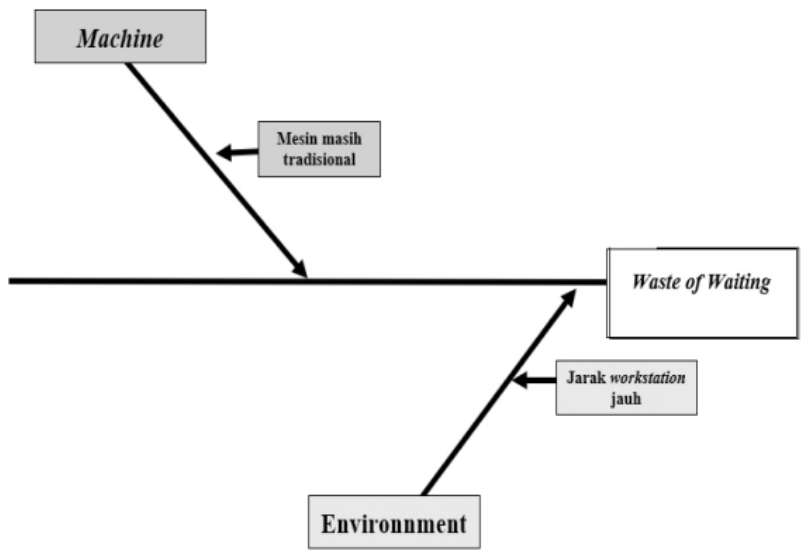

Gambar 5 Waste of Waiting

Waste of waiting memiliki skor 1,75. Pemborosan jenis waiting dapat dieliminasi mengguna- 
kan dua kategori yang terdapat pada diagram fishbone yaitu kategori machine dan environment. Jenis pemborosan berupa waiting disebabkan oleh beberapa hal seperti penggunaan mesin yang masih tradisional. Proses produksi sapu memiliki dua tempat produksi yang terpisah jauh. Dapat dilihat pada tabel PAM bahwa untuk memindahkan barang dari proses pemasangan ke proses quality control membutuhkan waktu 30 menit lamanya dan harus menempuh jarak $17 \mathrm{~km}$ jauhnya. Keterlambatan yang terjadi pada proses pemindahan ini akan mengakibatkan berhentinya proses pada QC dan proses-proses setelah QC karena proses produksi sapu memiliki urutan sistematis yang tidak dapat diloncati sebelum proses sebelumnya selesai.

\section{Waste of Unnecessary Inventory}

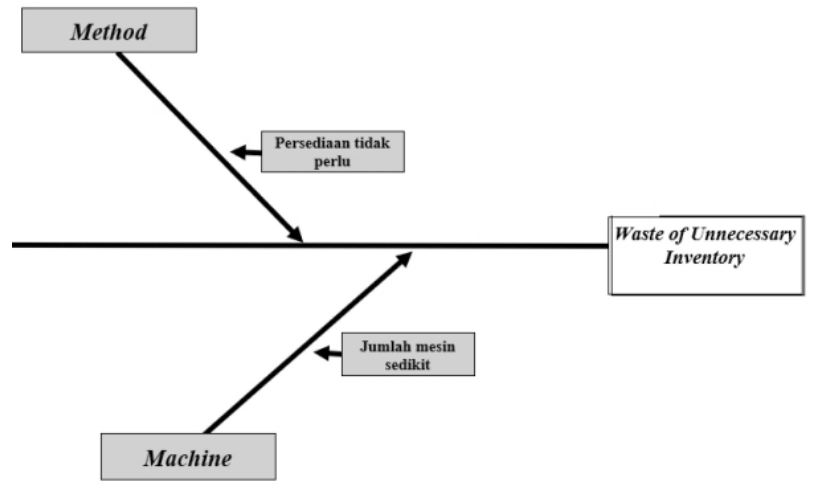

Gambar 6 Waste of Unnecessary Inventory

Waste of unnecessary inventory memiliki skor yang sama dengan pemborosan jenis waiting yaitu 1,75 dari hasil perhitungan kuesioner sehingga tingkat urgensi untuk dihilangkan juga sebesar pemborosan jenis waiting.

Pemborosan berupa persediaan terlihat pada tabel process activity mapping (PAM) di mana proses penyimpanan sementara menghabiskan banyak waktu yaitu sebesar 4.320 menit untuk penyimpanan dan 15 menit untuk transpor.
Persediaan ini bersifat sementara sehingga dapat dihilangkan dari proses produksi.

Persediaan yang tidak perlu terjadi pada perpindahan proses pengemasan ke proses penggagangan. Proses pengemasan menggunakan alat yang memadai berupa cetakan, kaca, dan solder. Alat tersebut membantu karyawan untuk meningkatkan produktivitas mereka. Akan tetapi, penggunaan alat tidak diimbangi pada proses penggagangan. Pada proses ini karyawan hanya menggunakan sebilah pisau besar dan alas dari batang kayu untuk meruncingkan gagang. Perbedaan alat ini memunculkan penumpukan produk pada proses penggagangan karena terdapat perbedaan kecepatan pada satu proses ke proses selanjutnya. Secara umum, pemborosan berupa unnecessary inventory memiliki korelasi dengan pemborosan berupa waiting. Oleh karena itu, usulan perbaikan dapat berhubungan satu sama lain.

Berdasarkan penjelasan poin-poin tersebut maka penyebab pemborosan dapat disusun ke dalam diagram fishbone secara umum dengan menggunakan kategori yang terdapat pada diagram tulang ikan yaitu man, method, material, machine, dan environment. Diagram fishbone untuk proses produksi sapu pada UD Executive Makmur Abadi dapat dilihat pada gambar berikut.

\section{Usulan Perbaikan}

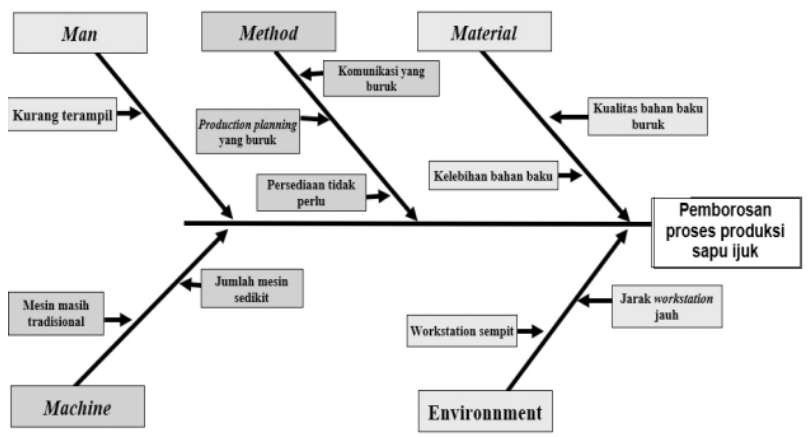

Gambar 7 Diagram Fishbone 
Dari analisis diagram fishbone maka dapat dilakukan usulan perbaikan berdasarkan empat tipe pemborosan teratas. Tipe pemborosan dianalisis berdasarkan penyebabnya menurut lima kategori yang terdapat pada diagram fishbone. Usulan dalam penelitian ini disajikan pada tabel berikut ini.

\section{Waste of Defect}

a. Man

- Memberikan pelatihan kepada karyawan secara intens untuk meningkatkan kekuatan kaitan senar.

- Memberikan pemahaman mendalam mengenai perawatan dan pemilahan ijuk secara benar untuk menghindari rework.

- Pemantauan kinerja untuk menjaga kualitas produk yang telah sesuai standar.

b. Material

- Mengganti kualitas plastik pembungkus yang lebih tebal agar tidak mudah robek.

c. Environment

- Mengubah ulang area kerja yang memiliki kerumitan pengerjaan tinggi menjadi lebih luas dengan mengurangi area kerja lain yang kerumitan pengerjaannya rendah.

\section{Waste of Overproduction}

a. Material

- Melakukan pembelian bahan baku menggunakan sistem economic order quantity (EOQ) untuk menghindari kelebihan material yang menyebabkan produksi berlebih.

- Pemilihan vendor yang memiliki kualitas bahan mirip satu sama lain.

b. Method

- Melakukan perbaikan perencanaan produksi secara konsisten.

- Memperbaiki aliran informasi.

\section{Waste of Waiting}

a. Machine

- Meningkatkan utilitas mesin yang telah ada.

b. Environment

- Menggabungkan dua workstation yang terpisah jauh yaitu proses pemasangan dan quality control menjadi satu pabrik sehingga dapat mengurangi waktu pengerjaan.

\section{Waste of Unnecessary Inventory}

a. Method

- Menghilangkan persediaan sementara antara proses quality control dengan proses penyisiran yang menghabiskan 4.335 menit dari total PLT.

b. Machine

- Pengadaan mesin terkini untuk proses penggagangan untuk meningkatkan dinamika proses produksi.

\section{Future State Mapping}

Future state mapping untuk proses produksi sapu pada UD Executive Makmur Abadi setelah adanya perbaikan disajikan dalam Gambar 8 .

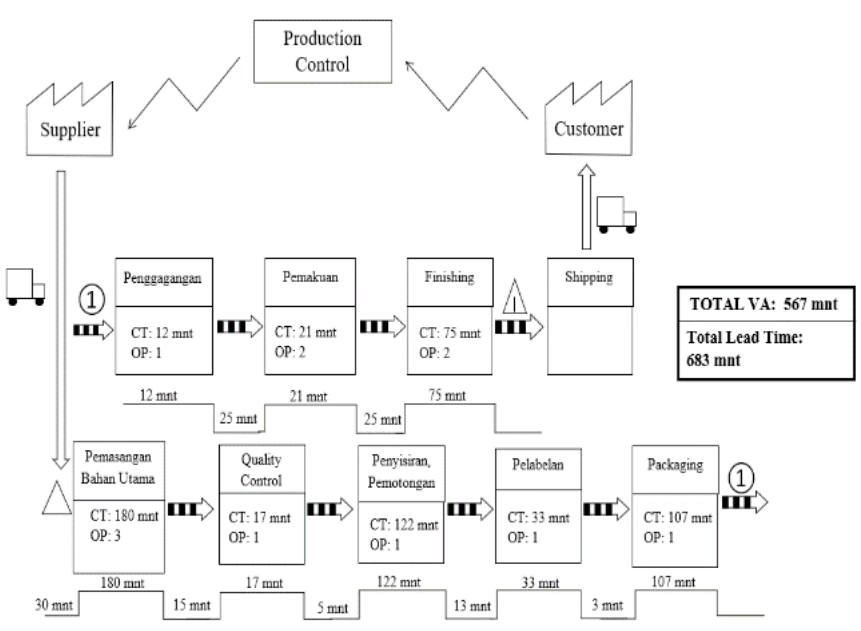

Gambar 8 Future State Map UD Executive Makmur Abadi 
Pada peta kondisi masa depan milik UD Executive Makmur Abadi dapat dilihat bahwa terjadi pengurangan total production lead time (PLT) yang awalnya 5028 menit setara dengan 3,5 hari menjadi 683 menit setara dengan 0,5 hari dengan total VA tetap yaitu 567 menit. Perubahan ini disebabkan karena terdapat eliminasi waktu transpor yang terjadi antara proses pemasangan ijuk dan proses quality control. Pengurangan waktu untuk mengurangi waktu transpor dengan mengintegrasikan proses produksi menjadi satu area. Pada awalnya proses pemasangan ijuk dilakukan di area terpisah dengan proses lainnya. Setelah dilakukan perbaikan maka proses pemasangan ijuk dilakukan di tempat produksi yang sama dengan proses lainnya sehingga dapat mereduksi lead time dari 30 menit menjadi 15 menit. Perubahan juga dilakukan pada eliminasi persediaan sementara yang terdapat di antara proses quality control dan proses penyisiran dan pemotongan. Perbaikan perencanaan produksi akan memberikan detail mengenai jumlah bahan yang akan dipesan kepada supplier. Material yang datang tidak akan melebihi dari perencanaan sehingga barang yang di proses di quality control tidak akan ada penumpukan karena dapat diproses langsung oleh bagian penyisiran dan pemotongan. Waktu yang dapat digunakan menjadi lebih pendek yaitu sebesar lima menit dibandingkan dengan waktu awal yang menghabiskan 4.335 menit.

\section{Process Activity Mapping Setelah Future State Mapping}

Pemetaan kondisi masa depan akan memengaruhi jumlah aktivitas pada tabel process activity mapping. Tabel PAM menunjukkan jumlah aktivitas yang terhitung sebagai lead time sebesar 5.120 menit dengan 23 aktivitas menjadi 22 aktivitas dan lead time sebesar 776 . Pengurangan aktivitas pada tabel PAM akan memengaruhi aktivitas VA, NVA, dan NNVA. Berikut adalah tabel ringkasan process activity mapping setelah future state mapping.

Tabel 4 Ringkasan Process Activity Mapping

\begin{tabular}{|c|c|c|c|c|c|c|}
\hline Aktivitas & Jumlah & Persentase & $\begin{array}{l}\text { Waktu } \\
\text { (menit) }\end{array}$ & Persentase & $\begin{array}{l}\text { Total } \\
\text { waktu }\end{array}$ & $\begin{array}{l}\text { Total } \\
\text { jarak }\end{array}$ \\
\hline Operation & 7 & $33,3 \%$ & 550 & $71,9 \%$ & \multirow{10}{*}{$\begin{array}{c}765 \\
\text { menit }\end{array}$} & \multirow{10}{*}{$\begin{array}{l}25,5 \\
\text { meter }\end{array}$} \\
\hline Transport & 10 & $47,6 \%$ & 153 & $20 \%$ & & \\
\hline Delay & 1 & $4,8 \%$ & 30 & $3,9 \%$ & & \\
\hline Inspection & 2 & $9,5 \%$ & 32 & $4,2 \%$ & & \\
\hline Storage & 1 & $4,8 \%$ & 0 & $0 \%$ & & \\
\hline Total & \multicolumn{2}{|r|}{21} & \multicolumn{2}{|c|}{765} & & \\
\hline VA & 7 & $33,3 \%$ & 550 & $71,9 \%$ & & \\
\hline NVA & 11 & $52,4 \%$ & 183 & $23,4 \%$ & & \\
\hline NNVA & 3 & $14,3 \%$ & 32 & $4,2 \%$ & & \\
\hline Total & \multicolumn{2}{|r|}{21} & \multicolumn{2}{|c|}{765} & & \\
\hline
\end{tabular}

\section{KESIMPULAN DAN SARAN}

Kesimpulan dari penelitian ini adalah sebagai berikut.

1. Identifikasi pemborosan dilakukan dengan pembobotan kuesioner yang dibagikan kepada karyawan produksi yang melakukan proses produksi secara langsung. Hasil dari pembobotan diketahui empat jenis pemborosan yang terjadi yaitu defects sebesar $21,95 \%$, overproduction sebesar 19,51\%, waiting 17,07\%, dan unnecessary inventory sebesar $17,07 \%$.

2. Analisis pemborosan dilakukan dengan memilih tools VALSAT yang memiliki nilai tertinggi. Pada penelitian ini menggunakan tools process activity mapping (PAM) dengan nilai terbesar yaitu 53 dibandingkan dengan 7 tools yang lainnya.

3. Berdasarkan PAM, diketahui terjadinya pemborosan berupa non-value added (NVA) yang memakan waktu sebesar 4.538 menit atau $88,7 \%$ dari total waktu produksi. NVA sebagian besar terjadi karena aktivitas delay dan transport. Delay terjadi ketika proses berhenti karena menunggu kedatangan bahan baku 
dari proses sebelumnya, mesin yang kurang memadai sehingga membuat proses berlangsung lama, dan proses penyimpanan sementara yang seharusnya dapat dieliminasi. Sedangkan transpor terjadi karena jarak dari proses satu ke proses lainnya terlalu jauh.

4. Analisis akar penyebab masalah juga dilakukan menggunakan diagram fishbone. Faktor penyebab terjadinya waste menurut diagram fishbone adalah sebagai berikut.

a. Man terjadi karena para pekerja kurang terampil dan teliti dalam memilah bahan utama sehingga diperlukan proses pengerjaan ulang (rework).

b. Method terjadi karena komunikasi yang buruk, perencanaan produksi yang belum tepat, dan penggunaan persediaan yang seharusnya tidak perlu karena produk tidak langsung diproses.

c. Material terjadi karena kualitas bahan baku yang buruk seperti lakop sapu terlalu tipis dan plastik pembungkus mudah sobek. Selain itu, pemilihan vendor yang kurang tepat memengaruhi kualitas dan kuantitas bahan baku yang digunakan.

d. Machine terjadi karena jumlah mesin yang digunakan tidak seimbang pada setiap sehingga menyebabkan perbedaan kecepatan produksi. Selain itu, mesin yang digunakan masih tradisional sehingga menghabiskan banyak waktu untuk memproduksi barang.

e. Environment terjadi karena area kerja yang terlalu sempit mengakibatkan cacat produk dan jarak antar proses yang terlalu jauh mengakibatkan lamanya waktu tunggu.

Kemudian saran untuk penelitian selanjutnya adalah sebagai berikut.

1. Penelitian dilakukan pada perusahaan yang lebih besar dan tingkat kerumitan pekerjaan- nya tinggi sehingga hasil dari penelitian dapat beragam.

2. Penelitian dilakukan pada perusahaan nonmanufaktur sehingga peneliti mendapatkan pandangan baru tentang pemborosan, value stream mapping, dan diagram fishbone. Sedangkan saran yang dapat diberikan untuk perusahaan adalah sebagai berikut.

a. Memberikan pelatihan kepada karyawan secara intens untuk meningkatkan kemampuan sehingga tidak terjadi cacat pada produk dan memantau kinerja untuk menjaga kestabilan kinerja.

b. Melakukan pemilihan ulang vendor yang memiliki kualitas homogen dan dapat diajak kerjasama dalam kesepakatan peraturan pembelian bahan baku.

c. Melakukan perbaikan perencanaan produksi dengan menggunakan sistem economic order quantity (EOQ) untuk menghindari kelebihan material yang menyebabkan pemborosan produksi berlebih.

d. Mengubah layout kerja di mana proses yang memiliki tingkat pengerjaan rumit diberikan area luas dan menggabung dua proses yaitu pemasangan bahan utama dan quality control yang terpisah jauh menjadi satu area di pabrik utama untuk mengurangi pemborosan jenis waiting.

e. Menghilangkan persediaan sementara antara process quality control dengan proses penyisiran yang menghabiskan 4.335 menit dari total production lead time sebesar 5.120 menit.

f. Melakukan pengadaan mesin untuk proses yang belum menggunakan mesin dan meningkatkan mesin (alat) yang telah digunakan pada proses tersebut untuk mengurangi pemborosan waiting dan unnecessary inventory. 


\section{DAFTAR PUSTAKA}

Gasperz, V. 2002. Manajemen Kualitas dalam Industri Jasa. Jakarta: PT. Gramedia Pustaka Utama.

Goriwondo, W. M., Mhlanga, S., \& Marecha, A. 2011. Use of the Value Stream Mapping Tool for Waste Reduction in Manufacturing. Case Study for Bread Manufacturing in Zimbabwe. Proceedings of the 2011 International Conference on Industrial Engineering and Operations Management, (pp. 1-6). Kuala Lumpur.

Hines, P. \& Rich, N. 1997. The Seven Value Stream Mapping Tools. International Journal of Operation \& Production Management, 48.

Islam, M., Naisra, S., Pritom, S. T., \& Rahman, M. A. 2016. Application of Fishbone Analysis for Evaluating Supply Chain and Business Process- A Case Study on KMART .Industrial Engineering Letters, 36-42.

Jasti, N. \& Sharma, A. 2014. Lean Manufacturing Implementation Using Value Stream Mapping as a Tool: A Sace Study from
Auto Component Industry. International Journal of Lean Six Sigma, 89-116

Kalsaas, B. 2002. Value Stream Mapping: An Adequate Method for Going Lean? Proceedings of the 14th International Conference NOFOMA 2002, (pp. 1-20). Trondheim.

Kompas.com. 2019. Potensi Bangkitnya UMKM dan Industri Kreatif melalui "Peer-to-Peer Lending”. Diakses pada 18 November 2019, dari https://ekonomi.kompas.com/ $\mathrm{read} / 2017 / 04 / 04 / 123000526 /$ potensi-bangkitnya-umkm-dan-industri-kreatif-melaluipeer-to-peer-lending-? page $=$ all .

Liker, J.K. 1998. Becoming Lean. Portland: Productivity Press.

Rother, M. \& Shook, J. 2003. Learning to See: Value Stream Mapping to Add Value and Eliminate Muda. Cambridge: Lean Enterprise Institute.

Womack, J. \& Jones, D. 2003. Lean Thinking: Banish Waste and Create Wealth in Your Corporation. Second Edition. London: Free Press Business. 
Accounting and Management Journal, Vol. 4, No. 2, December 2020 